\title{
\#StopAbleism: Reduksi Stigma kepada Penyandang Disabilitas melalui Intervensi Bias Implisit
}

\author{
Cleoputri Yusainy ${ }^{1}$, Slamet Thohari², \& Rachmad Gustomy ${ }^{3}$
}

Fakultas Ilmu Sosial dan Ilmu Politik Universitas Brawijaya Malang

\begin{abstract}
Two levels of stigma towards persons with disabilities have been identified, namely explicit and implicit stigma. This experiment aimed to explore whether these two levels of stigma were related to each other, and whether implicit bias intervention could be used as means to reduce explicit stigma. Participants $(N=98)$ were divided into three groups of those who initially completed measures of (1) explicit stigma (control group), (2) implicit stigma, followed by immediate feedback, and (3) implicit stigma, followed by explicit stigma and delayed feedback. Implicit stigma and implicit bias feedback were assessed through a computer-based response-latency task known as Single-Category Implicit Association Test (SC-IAT), explicit stigma was rated through self-report questionnaires. As predicted, no correlation was found between implicit and explicit stigma, and reductions in explicit stigma were shown amongst delayed feedback participants. These findings highlight the short-term benefits of implicit bias intervention on ableism.
\end{abstract}

Keywords: ableism, explicit stigma, implicit bias feedback, implicit stigma, SC-IAT

\begin{abstract}
Abstrak. Stigma kepada penyandang disabilitas beroperasi pada dua level: eksplisit dan implisit. Penelitian eksperimen ini bertujuan untuk menguji sejauh mana asosiasi antara kedua level stigma, dan apakah intervensi bias implisit dapat mereduksi stigma eksplisit. Partisipan $(N=98)$ dibagi ke dalam tiga kelompok kondisi eksperimen, yaitu kelompok yang lebih dahulu mengerjakan (1) kuesioner stigma eksplisit (kondisi kontrol), (2) instrumen stigma implisit, diikuti pemberian feedback bias implisit (kondisi feedback segera), dan (3) instrumen stigma implisit, diikuti kuesioner stigma eksplisit dan pemberian feedback bias implisit (kondisi feedback tertunda). Stigma implisit dan feedback bias implisit diukur melalui adopsi computer-based response-latency task berupa SingleCategory Implicit Association Test (SC-IAT), stigma eksplisit diukur melalui kuesioner self-report. Hasil penelitian menunjukkan bahwa stigma implisit tidak memiliki korelasi dengan stigma eksplisit, dan bahwa pengerjaan SC-IAT yang diikuti oleh feedback yang tertunda dapat mereduksi sebagian stigma eksplisit. Intervensi bias implisit berpotensi mengurangi praktik ableism, setidaknya dalam jangka pendek.
\end{abstract}

Kata kunci: ableism, feedback bias implisit, SC-IAT, stigma eksplisit, stigma implisit

Korespondensi mengenai isi artikel ini dapat dilakukan melalui: ${ }^{* 1}$ cleo.yusainy@ub.ac.id, ${ }^{2}$ sthohari@ub.ac.id, \&3gustomy@ub.ac.id 
Beberapa bulan lalu, hashtag \#StopAbleism menjadi trending topic di kalangan pengguna sosial media twitter. Istilah ableism diperkenalkan pertama kali pada tahun 1980-an oleh gerakan pembela hak-hak penyandang disabilitas di Amerika Serikat (News Ouch BBC, 2014). Secara umum, ableism merujuk pada praktik diskriminasi yang merendahkan dan membatasi potensi penyandang disabilitas. Praktik ini merentang mulai dari pemberian komentar dan label negatif, pelecehan, isolasi sosial, sampai pada penetapan kebijakan atau prosedur organisasi yang bersifat mengucilkan. Ableism menciptakan invisible barriers bagi penyandang disabilitas untuk terlibat secara penuh dalam komunitas (World Health Organization/ WHO, 2001). Di Indonesia, diskriminasi berdasarkan disabilitas adalah pelanggaran terhadap martabat dan nilai yang melekat pada setiap orang (Undang-Undang Republik Indonesia Nomor 19 Tahun 2011). Salah satu upaya nyata untuk melawan ableism adalah promosi penggantian label "penyandang cacat" yang digunakan sebelum tahun 1990-an menjadi "penyandang disabilitas", dan lebih jauh lagi menjadi "difabel" (differently abled people) atau individu yang mempunyai kemampuan berbeda (Thohari, 2013).

Pendekatan klasik Affect-BehaviorCognition (ABC) theory of attitudes memandang diskriminasi sebagai elemen perilaku yang bersama-sama dengan elemen kognitif (stereotipe) dan elemen afektif (prasangka) akan menciptakan suatu stigma (Stier \& Hinshaw, 2007). Dengan demikian, stigma merupakan sikap negatif yang diarahkan kepada nilai, karakteristik, atau praktik yang berada di luar norma umum. Stigma bahwa penyandang disabilitas "harus diperbaiki" menghasilkan angka marjinalisasi yang amat besar, mengingat $15 \%$ populasi dunia mengalami disabilitas dalam bentuk tertentu (World Health Organisation \& World Bank, 2011), dan prevalensi penyandang disabilitas di Indonesia adalah 11\% (Riset Kesehatan Dasar, 2013). Akibat stigma, disabilitas yang tadinya bersifat spesifik dapat mengalami transformasi menjadi kegagalan menyeluruh dalam kehidupan personal, keluarga, sosial, dan karir.

Studi awal mengenai stigma kepada penyandang disabilitas sebagian besar dilakukan melalui kuesioner self-report, dengan fokus kajian terhadap sikap eksplisit yang disadari dan dapat dikendalikan oleh subjek pemberi stigma. Pengukuran ini rentan terhadap social desirability bias karena respons yang ditampilkan subjek dapat diatur sedemikian rupa agar sejalan dengan norma sosial. Akurasi hasil pengukuran ini tergantung pula pada kecakapan subjek dalam melakukan introspeksi diri. Dampaknya, pengukuran stigma eksplisit tidak mampu merepresentasikan kompleksitas stigma yang sesungguhnya dimiliki subjek kepada target stigma (Banaji, Nosek, \& Greenwald, 2004; Stier \& Hinshaw, 2007). Secara lebih mendasar, stigma tidak sekadar beroperasi di level eksplisit. Stigma berakar pada sikap implisit yang teraktivasi secara otomatis tanpa disadari oleh pemberi stigma (Antonak \& Livneh, 2000). Temuan penelitian di bidang neurosains mendukung bahwa interaksi dengan kelompok target stigma akan mengaktifkan amygdala di area subkortikal otak, jauh di bawah kendali kognitif di area prefrontal (Amodio, 2014).

Satu terobosan untuk mengukur stigma implisit adalah melalui paradigma computer-based response-latency task yang dinamai Single Category Implicit Association Test (SC-IAT; Karpinski \& Steinman, 2006). Paradigma ini telah 
divalidasi dalam real-world setting untuk penelitian stigma berdasarkan ras, religi, jenis kelamin, orientasi seksual, sampai pilihan politik dan berat badan (Bar-Anan \& Nosek, 2014; Nosek et al., 2007). Sebagai gambaran, dalam SC-IAT berdasarkan disabilitas, partisipan diminta memberikan respons terhadap suatu kategori tunggal (contoh: Penyandang Disabilitas) dan dua atribut alternatif (contoh: Atribut negatif vs. Atribut positif). Bias implisit diukur melalui selisih waktu reaksi yang dibutuhkan partisipan untuk memasangkan kategori dengan atribut tertentu, dimana waktu reaksi yang lebih cepat menandakan asosiasi otomatis yang lebih kuat. Penelitian dengan SC-IAT oleh Wang, Huang, Jackson, dan Chen (2012) mengindikasikan bahwa walaupun mahasiswa di Cina tidak melaporkan stigma pada level eksplisit, lebih dari $60 \%$ mahasiswa ternyata memiliki bias implisit negatif kepada penyandang gangguan mental. Meskipun demikian, belum ditemukan korelasi yang konsisten antara stigma implisit dan stigma eksplisit (Wilson \& Scior, 2014). Pemetaan pola korelasi antara kedua level stigma tersebut adalah tujuan pertama dari penelitian ini.

Teori-teori mapan mengenai selfcontrol seperti feedback loops theory (Carver \& Scheier, 1982) dan self-regulation of prejudice model (Monteith, Mark \& Ashburn-Nardo, 2010) memperlihatkan bahwa selain untuk mengukur stigma implisit, paradigma bias implisit mempunyai potensi untuk dimanfaatkan sebagai strategi intervensi terhadap diskriminasi. Self-control merujuk pada kapasitas mental subjek untuk secara sadar mengendalikan elemen kognitif, afektif, dan perilaku diri agar sesuai dengan standar yang ditetapkan (Inzlicht \& Legault, 2014). Self- control yang efektif menuntut adanya kemampuan untuk melakukan monitoring secara terus-menerus terhadap "cues for control" (Yusainy \& Lawrence, 2015). Dalam konteks stigma, cues for control bisa berupa stimulus dari lingkungan seperti kata dan gambar yang memiliki asosiasi dengan disabilitas, atau kontak langsung dengan penyandang disabilitas. Ketika subjek menyadari bahwa ia memiliki bias implisit negatif kepada penyandang disabilitas, hal ini bisa dinilai sebagai suatu kesenjangan karena bertentangan dengan standar subjek sendiri untuk diperlakukan secara adil (Monteith et al., 2010). Akibatnya, subjek akan melakukan upaya selfcontrol untuk mereduksi stigma yang ia miliki dalam aktivitas selanjutnya. Bukti awal untuk prediksi ini dihasilkan dari penelitian Menatti, Smyth, Nosek, dan Teachman (2013) dimana partisipan yang lebih dahulu mengerjakan instrumen stigma implisit secara online selama lima menit melaporkan stigma eksplisit yang lebih rendah kepada penyandang gangguan mental, dibanding partisipan yang langsung mengerjakan kuesioner stigma eksplisit. Sejauh mana efektivitas paradigma ini untuk konteks disabilitas di Indonesia adalah tujuan kedua dari penelitian ini.

Secara lebih spesifik, penelitian ini bertujuan untuk mengetahui apakah terdapat korelasi antara stigma implisit dan stigma eksplisit kepada penyandang disabilitas (Hipotesis 1), dan apakah intervensi bias implisit memiliki pengaruh terhadap stigma eksplisit (Hipotesis 2). Hasil penelitian ini dapat dimanfaatkan sebagai masukan awal bagi para pemangku kepentingan untuk menyusun strategi intervensi inovatif terhadap diskriminasi berdasarkan disabilitas secara lebih komprehensif. 


\section{Metode}

Penelitian ini memakai between-groups experimental design (Gambar 1) dalam setting laboratorium. Intervensi bias implisit disajikan melalui variasi urutan pengerjaan instrumen stigma implisit dan pemberian informasi bias implisit (feedback bias implisit). Berdasarkan urutan perlakuan, partisipan dibagi ke dalam tiga kelompok kondisi, yaitu kondisi kontrol (Kondisi 1), kondisi dimana feedback bias implisit segera diberikan (Kondisi 2), dan kondisi dimana feedback bias implisit ditunda pemberiannya (Kondisi 3). Urutan perlakuan adalah variabel prediktor $(X)$ dan stigma eksplisit adalah variabel kriterium $(\mathrm{Y})$.

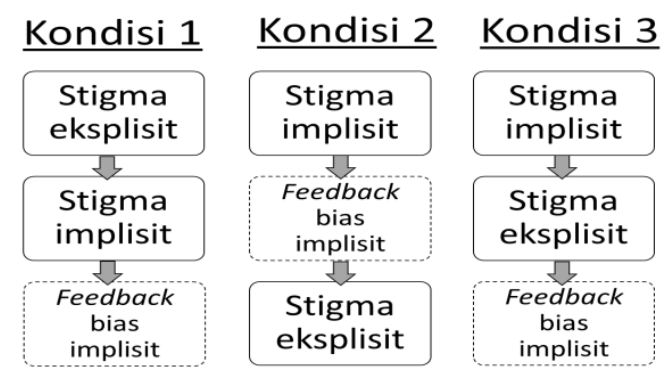

Gambar 1. Desain penelitian \#StopAbleism (Replikasi Menatti, Smyth, Nosek, \& Teachman, 2013)
Partisipan penelitian adalah mahasiswa Fakultas ' $\mathrm{I}$ ' Universitas 'B' yang direkrut melalui poster yang dipublikasikan di lingkungan kampus. Untuk mengurangi social desirability, dalam informasi mengenai eksperimen dinyatakan bahwa partisipan akan mengikuti suatu lomba kecepatan reaksi, dimana tiga partisipan yang memberikan respons paling cepat dan akurat berhak memeroleh hadiah sebesar Rp 300.000,00; Rp 200.000,00; dan Rp 150.000,00. Dari total 103 partisipan yang mengikuti eksperimen, lima partisipan dinyatakan gugur karena data corruption sehingga jumlah partisipan final adalah 98 (lihat Tabel 1). Dapat disimpulkan bahwa dalam setiap kondisi eksperimen, partisipan tersebar setara dalam aspek usia, jenis kelamin, pengalaman disabilitas, dan pengalaman dengan penyandang disabilitas. Sebagian besar partisipan tidak pernah mengalami disabilitas (91,80\%) dan sangat jarang punya pengalaman intensif dengan penyandang disabilitas $(92,60 \%$ partisipan melaporkan mendapat nilai rerata kurang dari mid-point 3).

Tabel 1

Data demografis partisipan

\begin{tabular}{lllll}
\hline \multicolumn{1}{c}{ Data } & $\begin{array}{r}\text { Kondisi 1 } \\
(n=35)\end{array}$ & $\begin{array}{c}\text { Kondisi 2 } \\
(n=30)\end{array}$ & $\begin{array}{c}\text { Kondisi 3 } \\
(n=33)\end{array}$ & $\begin{array}{c}\text { Total }^{\text {a }} \\
(N=98)\end{array}$ \\
\hline Usia (tahun: $M ; S D)$ & $20,29(0,99)$ & $20,33(1,18)$ & $20,94(1,16)$ & $20,90(1,17)$ \\
Jenis kelamin (perempuan: n; \%) & $19(54,30 \%)$ & $15(46,90 \%)$ & $20(58,80 \%)$ & $54(53,50 \%)$ \\
Pengalaman disabilitas (permanen, & $0 ; 3(8,60 \%) ;$ & $0 ; 0 ; 30$ & $2(6,10 \%) ;$ & $2(2,00 \%) ;$ \\
temporer, tidak pernah: n; \%) & $32(91,40 \%)$ & $(100 \%)$ & $3(9,10 \%) ;$ & $6(6,10 \%) ;$ \\
& & & $28(84,80 \%)$ & $90(91,80 \%)$ \\
Pengalaman dengan penyandang & $1,87 \mathrm{a}$ & 2,17 & 2,06 & 2,03 a
\end{tabular}

disabilitas (mid-point: 3; rentang 1-5)

Ket. Kondisi 1: Stigma eksplisit - stigma implisit - feedback bias implisit; Kondisi 2: Stigma implisit feedback bias implisit - stigma eksplisit; Kondisi 3: Stigma implisit - stigma eksplisit - feedback bias implisit.

a Berdasarkan analisis statistical power dengan G*Power v.3.1 (Erdfelder, Faul, \& Buchner, 2007), untuk alpha level sebesar 0,05 dan power sebesar 0,80 diperlukan total sampel $N \geq 66$ untuk memeroleh large effect $(d=0,40)$.

b Khusus untuk data pengalaman dengan penyandang disabilitas, $n$ Kondisi $1=32$ ( 3 partisipan tidak memberikan informasi); $N=95$. 


\section{Prosedur penelitian}

Partisipan datang ke laboratorium komputer secara berkelompok berdasarkan alokasi kelompok kondisi eksperimen. Setelah membaca informasi mengenai eksperimen dan menandatangani formulir persetujuan (informed consent), partisipan diminta untuk mengisi data demografis (usia, jenis kelamin, riwayat disabilitas partisipan, dan pengalaman dengan penyandang disabilitas). Partisipan kemudian melengkapi instrumen stigma implisit, kuesioner stigma eksplisit, dan menerima feedback bias implisit melalui layar komputer (Urutan perlakuan didasarkan pada alokasi kelompok kondisi eksperimen). Debrief mengenai hipotesis penelitian dilakukan setelah seluruh kegiatan eksperimen selesai.

Stigma implisit. Stigma pada level implisit adalah sikap negatif yang diarahkan kepada nilai, karakteristik, atau praktik di luar norma umum, yang bersifat intuitif, otomatis, dan tidak disadari oleh subjek pemberi stigma (Stier \& Hinshaw, 2007). Stigma implisit mencakup elemen evaluasi kognitif (stereotipe), elemen reaksi afektif (prasangka), dan elemen perilaku (diskriminasi). Ketiga elemen ini berpotensi menjadi mediator (mekanisme yang mendasar) atas keyakinan yang dimiliki subjek kepada target stigma. Stigma implisit kepada penyandang disabilitas digali melalui paradigma computer-based response-latency task, berupa instrumen SC-IAT (Karpinski \& Steinman, 2006) yang disajikan dengan software Inquisit v.4.0.8.0. (2014).

Terdapat tiga kategori stimulus dalam SC-IAT, yaitu kategori (1) target berupa simbol yang merepresentasikan penyandang disabilitas (4 stimulus target), (2) atribut positif (12 atribut), dan (3) atribut negatif (12 atribut). Stimulus target diperoleh dari penelitian Nosek et al.
(2007; Gambar 2). Stimulus atribut merupakan modifikasi dari penelitian Wang et al. (2012) yang telah disesuaikan dengan survei awal peneliti mengenai stigma kepada penyandang disabilitas di Indonesia. Setiap stimulus atribut tersusun atas elemen kognitif, afektif, dan perilaku (Tabel 2).

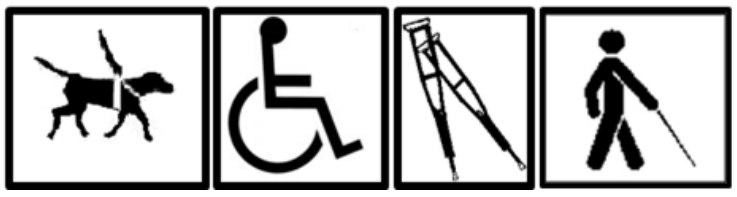

Gambar 2. Simbol target penyandang disabilitas (Nosek et al., 2007)

Tabel 2

Stimulus atribut untuk elemen dalam SingleCategory Implicit Association Test (SC-IAT)

\begin{tabular}{|c|c|c|}
\hline \multirow{2}{*}{ Elemen } & \multicolumn{2}{|c|}{ Atribut } \\
\hline & Positif & Negatif \\
\hline SC-IAT & terpuji, kompeten & berbahaya, \\
\hline kognitif & harga diri, kuat & $\begin{array}{l}\text { abnormal, rapuh, } \\
\text { menyedihkan }\end{array}$ \\
\hline $\begin{array}{l}\text { SC-IAT } \\
\text { afektif }\end{array}$ & $\begin{array}{l}\text { gembira, santai, } \\
\text { riang, ceria }\end{array}$ & $\begin{array}{l}\text { bosan, takut, } \\
\text { gugup, jijik }\end{array}$ \\
\hline $\begin{array}{l}\text { SC-IAT } \\
\text { perilaku }\end{array}$ & $\begin{array}{l}\text { pendekatan, } \\
\text { menghormati, } \\
\text { peduli, mengajak }\end{array}$ & $\begin{array}{l}\text { ditolak, kabur, } \\
\text { menghina, } \\
\text { menghindar }\end{array}$ \\
\hline
\end{tabular}

Instrumen SC-IAT (Tabel 3) terdiri atas level incompatible (disabilitas dipasangkan atribut positif) dan compatible (disabilitas dipasangkan atribut negatif). Penyajian stimulus pada level compatible incompatible selalu diawali dengan instruksi mengenai dimensi stimulus dan respons yang tepat. Pada level compatible, partisipan harus secepat-cepatnya menekan huruf " $\mathrm{Q}$ " pada keyboard jika muncul stimulus dari kategori "atribut positif", dan huruf "P" jika muncul stimulus dari kategori "penyandang disabilitas" atau "atribut negatif". Sebaliknya pada level incompatible, partisipan harus menekan huruf " $Q$ " jika muncul stimulus dari kategori "penyandang disabilitas" atau 
"atribut positif", dan huruf "P" jika muncul stimulus dari kategori "atribut negatif". Apabila partisipan salah merespons, muncul tanda $X$ warna merah di sisi bawah stimulus (150 ms). Partisipan harus merevisi respons dengan cara menekan huruf yang benar. Respons yang benar akan diikuti oleh tanda $\mathrm{O}$ warna hijau pada sisi bawah stimulus (150 ms). Skor reliabilitas level incompatible adalah sebesar 0,92 dan level compatible sebesar 0,84.

Mengikuti rekomendasi Greenwald, Nosek, dan Banaji (2003), kekuatan asosiasi antar kategori diukur dari standardised mean difference score (D-score, setara dengan effect size) pada level incompatible dan level compatible. D-score adalah selisih rerata latensi respons pada level compatible dikurangi rerata latensi respons pada level incompatible dibagi dengan standar deviasi seluruh latensi respons dari seluruh jawaban yang benar pada kedua level ini. Makin negatif $D$ score, makin kuat asosiasi antara penyandang disabilitas dengan atribut negatif. Makin positif $D$-score, makin kuat asosiasi antara penyandang disabilitas dengan atribut positif. Dalam penelitian ini, $D$ score akan ditinjau secara keseluruhan $(D-$ score kombinasi) dan pada setiap elemen stigma implisit.

Feedback bias implisit. Feedback bias implisit yang diberikan kepada partisipan dihitung berdasarkan hasil $D$-score kombinasi dari masing-masing partisipan (Menatti et al., 2013). Skor absolut 0,0 0,14 menghasilkan "tidak ada perbedaan" (tidak ada bias implisit), skor absolut 0,15 - 0,34 menghasilkan asosiasi implisit "lemah", skor absolut 0,35 - 0,64 menghasilkan asosiasi implisit "sedang", dan skor absolut 0,65 ke atas menghasilkan asosiasi implisit "kuat". Dengan demikian, terdapat tujuh kategori feedback bias implisit, yaitu asosiasi lemah, sedang, atau kuat terhadap penyandang disabilitas dengan atribut negatif ( $D$-score negatif); asosiasi lemah, sedang, atau kuat terhadap penyandang disabilitas dengan atribut positif ( $D$-score positif); atau tidak ada perbedaan asosiasi terhadap penyandang disabilitas dengan atribut positif vs. negatif.

Stigma eksplisit. Stigma pada level eksplisit adalah sikap negatif kepada nilai, karakteristik, atau praktik di luar norma umum, yang bersifat reflektif serta disadari dan dapat dikendalikan oleh subjek pemberi stigma (Stier \& Hinshaw, 2007). Stigma eksplisit kepada penyandang disabilitas diukur melalui modifikasi kuesioner self-report dari Wang dan kolega (2012) tentang stigma mahasiswa di Cina kepada individu dengan gangguan mental. Kuesioner pertama adalah Social Distance Scale (SDS) yang mengukur

Tabel 3

Struktur Single-Category Implicit Association Test (SC-IAT; Karpinski \& Steinman, 2006).

\begin{tabular}{|c|c|c|c|c|}
\hline Levela $^{\mathrm{a}}$ & Trialb $^{\mathrm{b}}$ & Kategori (kiri atas) & Kategori (kanan atas) & Rasio stimulus \\
\hline Compatible & $\begin{array}{l}24 \text { Practice } \\
72 \text { Test }\end{array}$ & Atribut positif & $\begin{array}{l}\text { Atribut negatif } \\
+ \text { Disabilitas }\end{array}$ & $\begin{array}{l}\text { Atribut negatif: Disabilitas: } \\
\text { Atribut positif }=7: 7: 10\end{array}$ \\
\hline Incompatible & $\begin{array}{l}24 \text { Practice } \\
72 \text { Test }\end{array}$ & $\begin{array}{l}\text { Atribut positif } \\
+ \text { Disabilitas }\end{array}$ & Atribut negatif & $\begin{array}{l}\text { Atribut positif: Disabilitas: } \\
\text { Atribut negatif }=7: 7: 10\end{array}$ \\
\hline
\end{tabular}

Ket. Compatible $=$ Disabilitas dipasangkan atribut negatif.

Incompatible $=$ Disabilitas dipasangkan atribut positif.

aUrutan level compatible-incompatible disajikan secara random kepada partisipan.

'Data practice trials tidak diolah untuk perhitungan $D$-score. 
kecenderungan partisipan untuk menghindar dari penyandang disabilitas. Partisipan membaca sebuah vignette tentang penyandang disabilitas bernama Dian, lalu menjawab lima tanyaan mengenai sejauh mana kesediaan mereka $(1=$ sangat enggan, 4 = sangat bersedia) untuk (1) menjadi tetangga Dian, (2) menghabiskan waktu bersosialisasi dengan Dian, (3) berteman dengan Dian, (4) bekerja dekat dengan Dian, dan (5) mengizinkan Dian menikahi anggota keluarga partisipan. Skor reliabilitas SDS sebesar 0.73. Kuesioner kedua adalah Feeling Thermometer (FT), dimana partisipan diminta menilai sejauh mana perasaan mereka kepada penyandang disabilitas. Kuesioner FT adalah skala analog visual dalam bentuk termometer dari rentang 1 (sangat negatif) sampai 100 (sangat positif). Makin rendah skor rerata SDS dan FT, makin tinggi stigma eksplisit yang dilaporkan oleh partisipan.

Korelasi antara stigma implisit ( $D$-score SC-IAT kombinasi, kognitif, afektif, dan perilaku) dan stigma eksplisit (skor total SDS dan FT) kepada penyandang disabilitas (Uji hipotesis 1) dianalisis dengan zero-order correlation. Pengaruh intervensi bias implisit terhadap stigma eksplisit (Uji hipotesis 2) dianalisis dengan dua kode orthogonal contrast sebagai prediktor dalam model regresi. Kode-1 mengkontraskan pengaruh ketika partisipan lebih dahulu mengerjakan kuesioner stigma eksplisit (Kondisi 1) vs. instrumen stigma implisit (dengan feedback segera maupun feedback tertunda; atau kombinasi Kondisi 2 dan 3). Kode-2 mengkontraskan pengaruh ketika partisipan lebih dahulu mengerjakan instrumen stigma implisit diikuti feedback segera vs. stigma implisit diikuti feedback tertunda. Sejalan hasil penelitian Menatti et al. (2013), pengerjaan instrumen stigma implisit diprediksi akan menurunkan stigma eksplisit kepada penyandang disabilitas, terlepas dari apakah feedback bias implisit diberikan dengan timing segera ataupun tertunda.

\section{$\mathrm{H}$ a $\mathrm{s}$ i 1}

\section{Preliminary analysis}

Tabel 4 memuat deskripsi data stigma eksplisit dan stigma implisit seluruh partisipan kepada penyandang disabilitas $(N=98)$. Untuk stigma eksplisit, partisipan melaporkan kesediaan untuk menjalin interaksi (nilai rerata SDS lebih dari midpoint 2,50 untuk seluruh partisipan), serta perasaan yang cukup hangat dan positif kepada penyandang disabilitas (nilai rerata FT lebih dari mid-point 50; 96\% partisipan memeroleh skor lebih dari midpoint). Artinya, stigma eksplisit yang dilaporkan partisipan kepada penyandang disabilitas cenderung rendah.

Sebaliknya, untuk stigma implisit, paired t-test menunjukkan bahwa partisipan lebih cepat menampilkan respons ketika disabilitas dipasangkan dengan atribut negatif (compatible) daripada dengan atribut positif (incompatible), SCIAT RT kombinasi: $t(97)=3,40 ; p=0,001$. Artinya secara implisit muncul stigma kepada penyandang disabilitas. Sebagai catatan, hasil perhitungan kategori feedback bias implisit dengan $D$-score kombinasi mengindikasikan bahwa asosiasi yang muncul dengan atribut negatif tersebut tergolong kategori lemah. 
Tabel 4

Properti psikometri stigma eksplisit dan stigma implisit $(N=98)$

\begin{tabular}{lll}
\hline Stigma & & M; SD \\
\hline SDS (mid-point 2,50; rentang 1-4) & & 3,$16 ; 0,38$ \\
FT (mid-point 50; rentang 1-100) & & 77,$82 ; 12,24$ \\
& Kecepatan reaksi RT compatible & 686,$26 ; 123,43^{* *}$ \\
SC-IAT kombinasi & Kecepatan reaksi RT incompatible & 722,$90 ; 133,12$ \\
& D-score & $-0,16^{\mathrm{a}}$ \\
& Kecepatan reaksi RT compatible & 737,$83 ; 163,63^{* *}$ \\
SC-IAT kognitif & Kecepatan reaksi RT incompatible & 788,$36 ; 164$ \\
& D-score & $-0,21^{\mathrm{a}}$ \\
& Kecepatan reaksi RT compatible & 693,$98 ; 183,21$ \\
SC-IAT afektif & Kecepatan reaksi RT incompatible & 720,$88 ; 144,37$ \\
& D-score & $-0,19 \mathrm{a}$ \\
SC-IAT perilaku & Kecepatan reaksi RT compatible & 746,$69 ; 147,97^{*}$ \\
& Kecepatan reaksi RT incompatible & 771,$52 ; 156,54$ \\
\hline
\end{tabular}

Ket. SDS = Social Distance Scale; FT = Feeling Thermometer . Semakin rendah skor SDS dan FT maka semakin tinggi stigma kepada penyandang disabilitas.

SC-IAT = Single-Category Implicit Association Test; RT = Reaction Time; Compatible = Disabilitas dipasangkan atribut negatif; Incompatible = Disabilitas dipasangkan atribut positif; $D$-score $=$ Standardised mean difference score.

${ }^{a}$ Asosiasi lemah dengan atribut negatif; ${ }^{\mathrm{b}}$ Tidak ada bias implisit.

${ }^{*} p<0,05 ;{ }^{* *} p<0,01$.

Analisis lanjutan pada setiap elemen stigma implisit (kognitif, afektif, perilaku) dengan paired $\mathrm{t}$-test menunjukkan bahwa kecenderungan untuk merespons lebih cepat ketika disabilitas dipasangkan atribut negatif daripada dengan atribut positif muncul pada elemen kognitif (SCIAT RT kognitif: $t(97)=2,93 ; p=0,004)$ dan perilaku (SC-IAT RT perilaku: $t(97)=2,08$; $p=0,04)$, namun tidak pada elemen afektif (SC-IAT RT afektif: $t(97)=1,42 ; p=0,16$ ). Di sisi lain, feedback bias implisit dengan $D$ score menunjukkan asosiasi lemah antara penyandang disabilitas dan atribut negatif pada elemen kognitif dan afektif, namun tidak ada bias implisit pada elemen perilaku. Dari sini dapat disimpulkan bahwa stigma implisit muncul secara konsisten pada elemen kognitif.
Korelasi stigma implisit dan stigma eksplisit

Sebagaimana ditunjukkan pada Tabel 5, tidak terdapat korelasi antara stigma implisit dengan stigma eksplisit partisipan (ps > 0,42; Hipotesis 1). Korelasi yang signifikan muncul secara terpisah antar elemen stigma implisit, serta antar kuesioner stigma eksplisit. Untuk stigma implisit, semakin rendah SC-IAT D-score kombinasi maka evaluasi kognitif, reaksi afektif, dan kecenderungan perilaku partisipan kepada penyandang disabilitas menjadi semakin negatif. Untuk stigma eksplisit, semakin tinggi kesediaan partisipan untuk berinteraksi dengan penyandang disabilitas (SDS), semakin positif pula perasaan yang ia laporkan kepada penyandang disabilitas (FT). 
Tabel 5

Korelasi stigma implisit dan stigma eksplisit $(N=98)$

\begin{tabular}{lccccc}
\hline Stigma & FT & SDS & $\begin{array}{c}\text { SC-IAT D-score } \\
\text { kombinasi }\end{array}$ & $\begin{array}{c}\text { SC-IAT D-score } \\
\text { kognitif }\end{array}$ & $\begin{array}{c}\text { SC-IAT D-score } \\
\text { afektif }\end{array}$ \\
\hline SDS & $0,42^{* * *}$ & & & & \\
SC-IAT D-score kombinasi & $-0,05$ & $-0,05$ & & & \\
SC-IAT D-score kognitif & $-0,02$ & $-0,05$ & $0,80^{* * *}$ & & \\
SC-IAT D-score afektif & $-0,06$ & $-0,08$ & $0,74^{* * *}$ & $0,57^{* * *}$ & \\
SC-IAT D-score perilaku & 0,03 & 0,03 & $0,70^{* * *}$ & $0,45^{* * *}$ & $0,44^{* * *}$ \\
\hline
\end{tabular}

Ket. SDS = Social Distance Scale $;$ FT = Feeling Thermometer SC-IAT = Single-Category Implicit Association Test; $D$-score $=$ Standardised mean difference score.

*** $p<0,001$.

Pengaruh intervensi bias implisit terhadap stigma eksplisit

Kategori feedback bias implisit yang dihitung berdasarkan hasil $D$-score kombinasi menunjukkan adanya asosiasi lemah antara target penyandang disabilitas dan atribut negatif untuk partisipan dalam Kondisi 1 dan 3 (Tabel 6). Namun D-score tidak dianalisis lebih jauh dalam model regresi pengaruh intervensi bias implisit terhadap stigma eksplisit (Hipotesis 2), karena korelasinya dengan stigma eksplisit partisipan untuk semua kondisi eksperimen tidak signifikan ( $p s>0,14$ ).

Model regresi untuk menguji Hipotesis 2 dibentuk dari dua kode orthogonal contrast. Kode-1 adalah kode orthogonal contrast bagi pengaruh urutan pengerjaan kuesioner stigma eksplisit lebih dahulu (Kondisi 1) vs. instrumen stigma implisit lebih dahulu (Kondisi 2 dan 3). Sementara Kode-2 mengkontraskan pengaruh timing pemberian feedback bagi partisipan yang lebih dahulu mengerjakan instrumen stigma implisit, yaitu dengan feedback segera (Kondisi 2) vs. feedback tertunda (Kondisi 3). Ketika kedua kode ini secara simultan menjadi prediktor bagi stigma eksplisit, Kode-1 tidak memengaruhi SDS $(p=0,33)$ maupun FT $(p=0,11)$, sedangkan Kode-2 tidak memengaruhi SDS $(p=0,17)$ namun berpengaruh terhadap FT $(p=$ $0,01)$.

Secara lebih spesifik, pengaruh Kode2 terhadap FT muncul ketika partisipan mengerjakan stigma implisit lebih dahulu namun tidak langsung diberi feedback bias implisit (Kondisi 3). Ketika partisipan langsung memeroleh feedback (Kondisi 2) maka skor FT partisipan tidak berbeda dengan partisipan yang lebih dahulu mengerjakan stigma eksplisit (Kondisi 1). Artinya meskipun partisipan melaporkan perasaan yang lebih hangat dan positif kepada penyandang disabilitas ketika ia menyadari bias implisitnya, namun hal ini hanya terjadi ketika ia tidak langsung diberi informasi mengenai sejauh mana bias implisit yang ia miliki. 


\section{YUSAINY, DKK}

Tabel 6

Properti psikometri stigma eksplisit dan implisit berdasarkan kondisi eksperimen

\begin{tabular}{lccc}
\hline Stigma & $\begin{array}{c}\text { Kondisi } 1 \\
(n=35: M ; S D)\end{array}$ & $\begin{array}{c}\text { Kondisi 2 } \\
(n=30: M ; S D)\end{array}$ & $\begin{array}{c}\text { Kondisi 3 } \\
(n=33: M ; S D)\end{array}$ \\
\hline SDS (mid-point 2,50; rentang 1-4) & 3,$11 ; 0,49$ & 3,$13 ; 0,37$ & 3,$26 ; 0,39$ \\
FT (mid-point 50; rentang 1-100) & 75,$09 ; 12,89$ & 75,$37 ; 11,31$ & 82,$94 ; 10,99$ \\
SC-IAT D-score kombinasi & $-0,21^{\mathrm{a}}$ & $-0,09^{\mathrm{b}}$ & $-0,16^{\mathrm{a}}$ \\
\hline
\end{tabular}

Ket. SDS = Social Distance Scale; FT = Feeling Thermometer. Semakin rendah skor SDS dan FT maka semakin tinggi stigma kepada penyandang disabilitas.

SC-IAT = Single-Category Implicit Association Test; $D$-score $=$ Standardised mean difference score. Kondisi 1 = Kondisi kontrol (stigma eksplisit lebih dahulu); Kondisi 2 = Feedback bias implisit segera diberikan; Kondisi 3 = Feedback bias implisit ditunda pemberiannya.

aAsosiasi lemah dengan atribut negatif; bTidak ada bias implisit.

Dummy coding: Kode-1 adalah kode orthogonal contrast bagi pengaruh pengerjaan stigma implisit lebih dahulu (terlepas dari timing pemberian feedback bias implisit) vs. stigma eksplisit lebih dahulu: -1 jika lebih dahulu mengerjakan stigma eksplisit, 0,5 jika lebih dahulu mengerjakan stigma implisit; Kode-2 adalah kode orthogonal contrast bagi pengaruh pengerjaan stigma implisit lebih dahulu dengan feedback segera vs. pengerjaan stigma implisit lebih dahulu tanpa feedback: 0 jika lebih dahulu mengerjakan stigma eksplisit, 0,5 jika lebih dahulu mengerjakan stigma implisit dan segera diikuti pemberian feedback, -0,5 jika lebih dahulu mengerjakan stigma implisit dengan feedback yang tertunda pemberiannya.

\section{Diskusi}

Intervensi terhadap ableism dan pengukuran efektivitas suatu intervensi hanya bisa berjalan optimal apabila stigma kepada penyandang disabilitas tertangkap secara akurat. Dari analisis awal, ditemukan bahwa stigma eksplisit kepada penyandang disabilitas yang dilaporkan oleh partisipan melalui kuesioner selfreport tergolong rendah. Data serupa sering dihasilkan oleh penelitian stigma eksplisit (lihat Rüsch, Corrigan, Todd, \& Bodenhausen, 2011; Wang, 2012; Yusainy, Herani, Dharmawan, \& Semedhi, 2016) karena pada tataran introspektif, subjek cenderung memberikan respons yang sesuai dengan harapan sosial. Utamanya bagi masyarakat Indonesia yang hidup dalam budaya kolektif, pengungkapan stigma secara terbuka sangat mungkin memunculkan konflik yang dihindari (Koentjaraningrat, 1985).

Informasi yang bersifat stigmatik mengambil bentuk bias implisit negatif, dimana dalam pengukuran latensi respons yang bersifat otomatis, partisipan lebih cepat mengasosiasikan penyandang disabilitas dengan atribut negatif dibandingkan dengan atribut positif. Stigma implisit dipengaruhi oleh banyak faktor seperti keyakinan subjek tentang masa depan, sensitivitas subjek terhadap konsep disabilitas, serta kontak yang dimiliki subjek dengan penyandang disabilitas (Wilson \& Scior, 2014). Analisis lanjutan terhadap elemen stigma implisit mengungkap bahwa asosiasi ini konsisten pada elemen kognitif (stereotipe), namun tidak pada elemen afektif (prasangka) dan perilaku (diskriminasi). Seperti halnya dalam penelitian sebelumnya (Peris, Teachman, \& Nosek, 2008; Wang et al., 2012), stereotipe bahwa disabilitas memiliki asosiasi dengan atribut berbahaya, abnormal, rapuh, dan menyedihkan teraktivasi secara konsisten tanpa disadari oleh subjek pemilik stigma. Teori klasik manajemen teror dari Solomon, Greenberg, dan Pyszczynski (1991) mengungkap bahwa stereotipe akan meningkat seiring peningkatan bayangan akan kematian (mortality 
salience). Secara intuitif, individu penyandang disabilitas fisik lebih membangkitkan mortality salience dibandingkan individu yang bukan penyandang disabilitas.

Lebih jauh, dalam penelitian ini tidak ditemukan korelasi yang signifikan antara stigma implisit dan stigma eksplisit (Hipotesis 1). Hasil ini memperkuat argumen bahwa kedua stigma tersebut mengukur konstruk yang independen dan terpisah (Stier \& Hinshaw, 2007). Sebagai konsekuensinya, intervensi terhadap ableism tidak dapat sekadar melibatkan pengukuran pada level eksplisit, namun harus dapat menggali stigma implisit yang berada pada tataran otomatis dan tidak disadari oleh subjek pemberi stigma. Dalam perspektif Psikologi kontemporer, bias implisit negatif bahkan dapat dimiliki oleh orang-orang dengan standar moral yang tinggi karena perilaku manusia tidak selalu termotivasi oleh pemikiran rasional yang berada pada ranah kesadaran (lihat Banaji et al., 2004).

Walaupun stigma eksplisit dalam penelitian ini tidak memiliki korelasi dengan stigma implisit, pengalaman partisipan dalam mengerjakan instrumen stigma implisit berbentuk kata dan gambar yang memiliki asosiasi dengan disabilitas (SC-IAT) dapat mereduksi sebagian stigma eksplisit mereka kepada penyandang disabilitas (Hipotesis 2). Dalam hal ini, kelompok partisipan yang mengerjakan SC-IAT lebih dahulu namun tidak langsung menerima feedback bias implisit (feedback tertunda) melaporkan perasaan yang lebih hangat dan positif kepada penyandang (FT), dibandingkan kelompok yang langsung memeroleh feedback (feedback segera) maupun kelompok kontrol. Hasil ini berbeda dengan temuan dari Menatti et al. (2013), dimana dalam penelitian mereka timing pemberian feedback bias implisit tidak berpengaruh terhadap reduksi stigma eksplisit. Perbedaan budaya partisipan dalam penelitian Menatti et al. dan dalam penelitian ini mungkin menjelaskan perbedaan peran dari timing pemberian feedback. Bagi masyarakat Barat, inkonsistensi dalam pikiran, perasaan, dan perilaku mereka cenderung mendorong tampilnya berbagai upaya untuk meningkatkan konsistensi konsep diri secara keseluruhan (Festinger, 1957). Pengalaman partisipan dalam mengerjakan instrumen stigma implisit dapat membangkitkan kesadaran bahwa telah terjadi kesenjangan antara sikap yang muncul secara otomatis (dalam bentuk stigma implisit) dengan sikap yang selama ini mereka anggap sebagai standar dalam berperilaku (sikap eksplisit). Dalam teori feedback loops (Carver \& Scheier, 1982), kesenjangan antara diri subjek dengan standar tersebut menjadi cues for control bahwa subjek harus melakukan operasi self-control untuk mengubah elemen kognitif, afektif, dan perilakunya. Sebagai akibatnya, pengerjaan instrumen stigma implisit dapat mengaktifkan cues for control untuk mereduksi stigma eksplisit selanjutnya, terlepas dari timing pemberian feedback. Masyarakat Timur lebih mudah menerima keberadaan kontradiksi dalam berbagai elemen diri (Heine \& Lehman, 1997). Feedback bias implisit yang diberikan secara langsung justru lebih berisiko untuk meningkatkan resistensi dalam mengubah stigma eksplisit kepada penyandang disabilitas.

\section{Kesimpulan}

Sejalan dengan dugaan awal, dalam penelitian ini tidak ditemukan korelasi antara stigma implisit dan stigma eksplisit kepada penyandang disabilitas. Meskipun stigma eksplisit yang dilaporkan partisipan melalui kuesioner tergolong rendah, pengukuran instrumen stigma implisit SC- 
IAT menunjukkan adanya bias implisit negatif, dimana partisipan lebih cepat mengasosiasikan penyandang disabilitas dengan atribut negatif dibandingkan dengan atribut positif. Stigma implisit partisipan muncul secara konsisten pada elemen kognitif (stereotipe), tetapi tidak ditemukan pola yang konsisten pada elemen afektif (prasangka) dan perilaku (diskriminasi).

Lebih jauh, intervensi bias implisit ternyata dapat mereduksi sebagian stigma eksplisit kepada penyandang disabilitas. Reduksi stigma eksplisit ini tergantung pada timing pemberian feedback bias implisit, dimana partisipan yang lebih dahulu mengerjakan instrumen stigma implisit dengan feedback tertunda melaporkan perasaan yang lebih hangat dan positif kepada penyandang disabilitas, dibandingkan partisipan yang langsung memeroleh feedback maupun kelompok kontrol. Meskipun demikian, intervensi bias implisit tidak memiliki pengaruh dalam mereduksi keengganan partisipan menjalin relasi sosial dengan penyandang disabilitas.

Terlepas dari keterbatasan yang ada, penelitian ini telah memberikan kontribusi bagi penyusunan strategi intervensi inovatif terhadap praktik diskriminasi berdasarkan disabilitas, setidaknya untuk jangka pendek. Kompleksitas stigma yang dihasilkan melalui penelitian dapat tergali pada level implisit melalui paradigma computer-based response-latency task, selain stigma pada level eksplisit yang dilaporkan melalui kuesioner self-report. Dengan lebih dahulu menyadarkan individu akan bias implisit yang dimiliki kepada penyandang disabilitas, intervensi atas ableism diharapkan dapat menjadi lebih efektif.
Saran

Salah satu keterbatasan dalam penelitian ini adalah jenis stigma yang diukur mencakup hanya stigma-publik kepada penyandang disabilitas fisik. Perbandingan hasil penelitian tentang stigmapublik vs. stigma-diri vs. stigma-keluarga perlu dilakukan karena penyandang disabilitas yang menginternalisasi stigmapublik sebagai stigma-diri cenderung memiliki prognosis kesehatan yang lebih buruk (Werner, Corrigan, Ditchman, \& Sokol, 2012), dan anggota keluarga target stigma menghadapi beban ganda berupa beban objektif terkait perawatan target stigma serta beban subjektif akibat penolakan sosial (Stier \& Hinshaw, 2007).

Selain itu, diperlukan studi lanjutan untuk mengetahui mekanisme yang mendasari perbedaan pengaruh dari timing pemberian feedback bias implisit terhadap stigma eksplisit. Untuk mengetahui apakah self-control memang memiliki kontribusi terhadap kesadaran subjek akan bias implisitnya, penelitian selanjutnya dapat memadukan paradigma bias implisit dengan paradigma kontemporer self-control, seperti the strength model (Baumeister, Vohs, \& Tice, 2007). Penelitian selanjutnya dapat pula menggali lebih jauh dinamika elemen stereotipe, prasangka, dan diskriminasi dalam stigma implisit. Di samping itu, efektivitas intervensi bias implisit dalam konteks stigma terhadap disabilitas lain di Indonesia seperti gangguan mental psikiatri dan disabilitas intelektual perlu diujicobakan. Pada akhirnya, kontribusi spesifik dari stigma implisit dan stigma eksplisit harus diteliti terhadap perilaku yang bersifat konkret dalam real-life setting. 


\section{Kepustakaan}

Amodio, D. M. (2014). The neuroscience of prejudice and stereotyping. Nature Reviews Neuroscience, 15, 670-682. http://dx.doi.org/10.1038/nrn3800

Antonak, R. F., \& Livneh, H. (2000). Measurement of attitudes towards persons with disabilities. Disability and Rehabilitation, 22(5), 211-224. http://dx.doi.org/10.1080/0963828002 96782

Banaji, M. R., Nosek, B. A., \& Greenwald, A. G. (2004). No place for nostalgia in science: A response to Arkes and Tetlock. Psychological Inquiry, 15(4), 279-310. http://dx.doi.org/10.1207/ s15327965pli1504_02

Bar-Anan, Y., \& Nosek, B. A. (2014). A comparative investigation of seven indirect measures of social cognition. Behavior Research Methods, 46, 668688. http://dx.doi.org/10.3758/s13428013-0410-6

Baumeister, R. F., Vohs, K. D., \& Tice, D. M. (2007). The strength model of selfcontrol. Current Directions in Psychological Science, 16(6), 351-355. http://dx.doi.org/10.1111/j.14678721.2007.00534.x.

Carver, C. S., \& Scheier, M. F. (1982). Control theory: A useful conceptual framework for personality-social, clinical and health psychology. Psychological Bulletin, 92(1), 111-135. http://dx.doi.org/10.1037/00332909.92.1.111

Faul, F., Erdfelder, E., Lang, A, \& Buchner, A. (2007). G*Power 3: A flexible statistical power analysis program for the social, behavioral, and biomedical sciences. Behavior Research Methods, 39(2), 175 - 191. http://dx.doi.org/10.3758/BF03193146
Festinger, L. (1957). A theory of cognitive dissonance. Stanford, CA: Stanford University Press.

Greenwald, A. G., McGhee, D. E., \& Schwartz, J. L. K. (1998). Measuring individual differences in implicit cognition: The implicit association test. Journal of Personality and Social Psychology, 74(6), 1646-1480. http:// dx.doi.org/10.1037/00223514.74.6.1464

Greenwald, A. G., Nosek, B. A., \& Banaji, M. R. (2003). Understanding and Using the Implicit Association Test: I. An Improved Scoring Algorithm. Journal of Personality and Social Psychology, 85(2), 197-216. http:// dx.doi.org/10.1037/0022-3514.85.2.197

Heine, S. J., \& Lehman, D. R. (1999). Culture, self-discrepancies, and selfsatisfaction. Personality and Social Psychology Bulletin, 25, 915-925. http://dx.doi.org/10.1177/0146167299 2511001

Inzlicht, M., \& Legault, L. (2014). No pain, no gain: How distress underlies effective self-control (and unites diverse social psychological phenomena). In J. Forgas \& E. HarmonJones (Eds.), The Control Within: Motivation and its Regulation (pp. 115132). New York: Psychology Press.

Karpinski, A., \& Steinman, R.B. (2006). The Single Category Implicit Association Test as a measure of implicit social cognition. Journal of Personality and Social Psychology, 91, 16-32. http:// dx.doi.org/10.1037/0022-3514.91.1.16

Koentjaraningrat. (1985). Javanese Culture. Singapore: Oxford University Press East Asia.

Menatti, A., Smyth, F. L., Teachman, B. A., \& Nosek, B. A. (2013). Reducing stigma toward individuals with 
mental illnesses: A brief, online manipulation. Stigma Research and Action. https://osf.io/8rf2b/files/

Millisecond Software. (2014). Inquisit (Version v.4.0.8.0) [Computer software]. Seattle, Washington.

Monteith, M. J., Mark, A. Y., \& AshburnNardo, L. (2010). The self-regulation of prejudice: toward understanding its lived character. Group Processes and Intergroup Relations, 13(2), 183$200 . \quad$ http://dx.doi.org/10.1177/ 1368430209353633.

News Ouch BBC. (16 Juni 2014). First there was racism and sexism, now there's ableism. Diunduh dari: http://www. bbc.com/news/blogs-ouch-27840472 tanggal 5 Januari 2015.

Nosek, B. A., Smyth, F. L., Hansen, J. J., Devos, T., Lindner, N. M., Ranganath, K. A., . . Banaji, M. R. (2007). Pervasiveness and correlates of implicit attitudes and stereotypes. European Review of Social Psychology, 18, 36-88. http://dx.doi.org/10.1080/ 10463280701489053

Peris, T. S., Teachman, B. A., \& Nosek, B. A. (2008). Implicit and explicit stigma of mental illness. Journal of Nervous and Mental Disease, 196(10), 752-760. http://dx.doi.org/10.1097/NMD.0b013 e3181879dfd.

Riset Kesehatan Dasar. (2013). Badan Penelitian dan Pengembangan Kesehatan Kementerian Kesehatan RI. Diunduh dari: http://www.depkes. go.id/resources/download/general/H asil\%20Riskesdas\%202013.pdf

Rüsch N., Corrigan, P. C., Todd, A. R., \& Bodenhausen, G. V. (2011). Automatic stereotyping against people with schizophrenia, schizoaffective, and affective disorders. Psychological
Research，186, 34-39. http://dx.doi. org/10.1016/j.psychres.2010.08.024

Solomon, S., Greenberg, J., \& Pyszczynski, T. (1991). A terror management theory of social behavior: The psychological functions of selfesteem and cultural worldviews. In M. P. Zanna (Ed.), Advances in experimental social psychology (Vol. 24, pp. 93-159). San Diego, CA: Academic Press.

Stier, A., \& Hinshaw, S. P. (2007). Explicit and implicit stigma against individuals with mental illness. Australian Psychologist, 42(2), 106$117 . \quad$ http://dx.doi.org/10.1080/ 00050060701280599.

Thohari, S. (2013). Disability in Java: Contesting Conceptions of Disability in Javanese Society after the Suharto Regime. LAP LAMBERT Academic Publishing.

Undang-Undang Republik Indonesia Nomor 19 Tahun 2011. (2011). Pengesahan convention on the rights of persons with disabilities (konvensi mengenai hak-hak penyandang disabilitas).

Wang, X., Huang, X., Jackson, T., \& Chen, R. (2012). Components of implicit stigma against mental illness among Chinese students. PLoS ONE 7(9): e46016.http:// dx.doi.org/10.1371/journal.pone.004601 6

Werner, S., Corrigan, P., Ditchman, N., \& Sokol, K. (2012). Stigma and intellectual disability: A review of related measures and future directions. Research in Developmental Disabilities, 33, 748-765. http://dx.doi. org/10.1016/ j.ridd.2011.10.009

Wilson, M. C., \& Scior, K. (2014). Attitudes towards individuals with disabilities as measured by the Implicit Association Test: A literature review. Research in Developmental Disabilities, 
35, 294-321. http://dx.doi.org/ 10.1016/j.ridd.2013.11.003

World Health Organization. (2001). International classification of functioning, disability and health. Geneva: World Health Organization.

World Health Organisation, \& World Bank. (2011). World report on disability. Diunduh dari: http://whqlibdoc.

who.int/publications/2011/978924068 5215_eng.pdf.

Yusainy, C., \& Lawrence, C. (2015). Brief mindfulness induction could reduce aggression after depletion. Conscious- ness and Cognition, 33(1), 125-134. http://dx.doi.org/10.1016/j.concog.201 4.12.008

Yusainy, C., Herani, I., Dharmawan, I. R. J., \& Semedhi, B. P. (2016). No health without mental health: Dinamika stigma kepada penyandang disabilitas fisik dan mental. Prosiding Seminar Nasional Kontribusi Akademisi dalam Pencapaian Pembangunan Berkelanjutan, K6-K12. Panitia Bidang Ilmiah Dies Natalis Universitas Brawijaya ke-53.

(i) Penelitian ini terselenggara atas dana hibah internal PNBP Fakultas Ilmu Sosial dan Ilmu Politik Universitas Brawijaya tahun 2015.

(ii) Peneliti mengucapkan terima kasih kepada Ignatius Ryan Jeffri Dharmawan, Bima Pustaka Semedhi, dan Riska Andari atas bantuan dalam pengumpulan data. 